PRZEGLĄD NAUK HISTORYCZNYCH 2018, R. XVII, NR 1

http://dx.doi.org/10.18778/1644-857X.17.01.02

ANDRZEJ M. BRZEZIŃSKI

UNIWERSYTET ŁÓDZKI*

\title{
Udział Oskara Haleckiego w obchodach 250 rocznicy odsieczy wiedeńskiej w 1933 roku
}

Streszczenie. Oskar Halecki, profesor Uniwersytetu Warszawskiego, znakomity znawca dziejów powszechnych i Polski, włączył się do obchodów 250 rocznicy odsieczy wiedeńskiej jako katolicki intelektualista. W opublikowanych $z$ tej okazji artykułach profesor podkreślał znaczenie udziału Polski w zwycięskiej nad Turkami bitwie pod Wiedniem 12 września 1683 r., która ocaliła chrześcijańska Europę i zachodnią cywilizację. Wskazywał, że Polska pod wodzą Jana III Sobieskiego wystapiła po raz kolejny w dziejowej roli „przedmurza” chrześcijaństwa, która odgrywała od XIV w. Pogląd ten przedstawił również w wygłoszonym po niemiecku referacie Oswobodzenie Wiednia i jego znaczenie dla Austrii, Polski $i$ Europy podczas uroczystej akademii z okazji polskich obchodów rocznicy wiedeńskiej w stolicy Austrii 13 września 1933 r. Punkt widzenia Haleckiego o Polsce świadomej dziejowego posłannictwa obrońcy chrześcijaństwa był zgodny $z$ oficjalnym stanowiskiem Kościoła, wyrażonym przez prymasa Augusta Hlonda w oficjalnych pismach i wystapieniach $z$ okazji obchodów 250 rocznicy zwycięstwa pod Wiedniem.

$\mathrm{W}$ artykule zatytułowanym $W$ rocznice odsieczy Wiednia, otwierajacym okolicznościowy numer redagowanego przez profesora „Miesięcznika Heraldycznego", Halecki porównywał historyczne znaczenie bitwy pod Wiedniem $z$ bitwa pod Grunwaldem. Uważał, że w tysiącletnich dziejach Polski te dwa zwycięstwa można by zestawiać jedynie z bitwa pod Warszawa z 1920 r. Wiedeń, tak samo jak Grunwald, był „czynem przewidującej myśli politycznej”. W jednym i drugim przypadku „słusznej broniono sprawy” oraz prawa narodów do samodzielnego bytu wbrew „zakusom obcych najeźdźców”. Halecki odrzucał występujący w publicystyce pogląd, że udział Rzeczypospolitej w odsieczy Wiednia i ocalenie Austrii było politycznym błędem, ponieważ w następnym stuleciu wzięła udział w rozbiorach polsko-litewskiego państwa. Pogląd taki uważał za anachroniczny, pragnący

*Wydział Filozoficzno-Historyczny, Instytut Historii, Katedra Historii Powszechnej Najnowszej, e-mail: ambrzezin@uni.lodz.pl. 
wytłumaczyć wydarzenia 1683 r. nie w świetle sytuacji ówczesnej, wytworzonej przez poprzednie wieki, lecz za pomocą wydarzeń wiele późniejszych, niepozostających $z$ odsiecza Wiednia w żadnym związku przyczynowym.

Słowa kluczowe: Oskar Halecki, prymas August Hlond, Polska, Austria, 250 rocznica, odsiecz Wiednia 1683 roku.



ładze państwowe i kościelne Drugiej Rzeczypospolitej nadały obchodom 250 rocznicy zwycięstwa pod Wiedniem wyjatkowa rangę. Za pomoca uroczystości jubileuszowym zamierzano dać dowód pamięci o udziale wojsk Rzeczypospolitej pod wodza Jana III Sobieskiego w odsieczy Wiednia i zwycięstwie nad Turkami 12 września 1683 r. Nawiazywano w ten sposób do wcześniejszych uroczystych obchodów okragłych rocznic zwycięstwa pod stolicą Austrii ${ }^{1}$. W całej Polsce powstawały komitety organizacyjne obchodów (ogólnokrajowy, wojewódzkie, miejskie i powiatowe), w których uczestniczyli politycy, przedstawiciele środowisk naukowych, artystycznych i duchowni. Zadbano również o zorganizowanie obchodów odsieczy wiedeńskiej za granica. Realizowały je polskie placówki dyplomatyczne i konsularne, zazwyczaj w porozumieniu $\mathrm{z}$ polonijnymi stowarzyszeniami w większości państw europejskich oraz w Stanach Zjednoczonych i Kanadzie ${ }^{2}$.

Oskar Halecki, profesor Uniwersytetu Warszawskiego, w którym od 1919 r. kierował Katedra Historii Europy Wschodniej, zaanga-

${ }^{1}$ Podczas polskich obchodów okragłych rocznic zwycięstwa pod Wiedniem, począwszy od 1783 r., podkreślano przede wszystkim rolę Jana III Sobieskiego w pokonaniu potęgi tureckiej. Gloryfikowano króla, „szlachcica-Polaka”, jako bohatera narodowego walczacego w obronie ojczyzny i wiary chrześcijańskiej. Por. J. Śliziński, Jan III Sobieski w literaturze narodów Europy, Warszawa 1979, s. 89-100, 129-144; M. Anusik, Z. Anusik, Jan III Sobieski w tradycji historycznej czasów stanisławowskich, "Acta Universitatis Lodziensis”, Folia Historica 22, 1985, s. 79-89; A. Galos, Obchody rocznicy wiedeńskiej $w$ XIX wieku, „Śląski Kwartalnik Historyczny Sobótka” 1980, t. XXXV, nr 2, s. 433-439; M. Rożek, Zwycięstwo Jana III Sobieskiego pod Wiedniem. Echa Wiktorii, Kraków 2008; K. Malis zew ski, Kult Jana III Sobieskiego i wiktorii wiedeńskiej (1683) w polskiej kulturze i tradycji, „Czasy Nowożytne” 2010, t. XXIII, s. 47-62; D. Wyb ra now ski, O niektórych mitach, nieścisłościach $i$ kontrowersjach $w$ kwestii tureckiej wyprawy na Wiedeń w 1683 r., „Balcanica Posnaniensa” [Poznań] 2014, t. XXI, s. 82-63.

${ }^{2}$ Por. M. Kun icki-Goldfinger, Obchody 250. rocznicy zwycięstwa Jana III pod Wiedniem w prasie polskiej roku 1933 (przeglad wstepny), „Studia Wilanowskie" [Warszawa] 2014, t. XXI, s. 73-87; Z. Maj, Obchody 250 rocznicy odsieczy wiedeńskiej wśród Polaków za granica ( $w$ świetle dokumentów z Archiwum Akt Nowych w Warszawie), „Studia Wilanowskie” 1983, t. IX, s. 39-84. 
żował się w obchody 250 rocznicy zwycięstwa pod Wiedniem $z$ racji wykonywanej profesji i wyznawanego katolickiego światopoglądu. Znakomity znawca dziejów powszechnych i Polski, ceniony w kraju i za granica, był żarliwym katolikiem. Wiara wyniesiona $z$ rodzinnego domu determinowała jego życie oraz działalność naukowo-badawcza i publiczna. W publicystyce i opracowaniach naukowych profesora istotne miejsce zajmowały dzieje Kościoła i kultury chrześcijańskiej. Jednocześnie angażował się w wiele inicjatyw związanych $z$ działalnością organizacji świeckich katolików, pełniąc odpowiedzialne funkcje w polskich i międzynarodowych stowarzyszeniach ${ }^{3}$. Znając biegle kilka języków obcych, wielokrotnie występował za granica na forum publicznym jako referent podczas uroczystości o charakterze religijnym. Było tak zwłaszcza od połowy lat dwudziestych, kiedy Halecki przestał stopniowo pełnić w Genewie i Paryżu etatowe funkcje w strukturach Ligi Narodów na rzecz międzynarodowej współpracy intelektualnej ${ }^{4}$.

Profesor cieszył się dużym uznaniem hierarchii kościelnej. Już w końcu lat dwudziestych miał ugruntowana opinię gorliwego „działacza katolickiego" w Stolicy Apostolskiej ${ }^{5}$. Pozostawał w kontakcie $z$ kardynałem Augustem Hlondem, prymasem Polski, który zapraszał profesora do udziału jako referenta w ważnych uroczystościach o charakterze państwowym i kościelnym bądź wyłącznie religijnym, przez siebie współorganizowanych bądź inspirowanych ${ }^{6}$.

${ }^{3}$ Od 1921 r. Halecki był członkiem Union Catholique d’études internationales we Fryburgu, założycielem i prezesem jej polskiej grupy w latach 1927-1929; od 1931 r. należał do Zjednoczenia Pisarzy Katolickich, którego był prezesem (1933-1936), należał do Związku Polskiej Inteligencji Katolickiej, pełniąc funkcję wiceprezesa Zarządu Głównego (1934-1935), był także aktywnym Akcji Katolickiej i federacji „Pax Romana”. Na emigracji w Stanach Zjednoczonych (1939-1973) profesor działał w Amerykańskim Stowarzyszeniu Pisarzy Katolickich, w latach sześćdziesiątych był jego prezesem. Por. A. Barwiak, Oskar Halecki, [w:] Encyklopedia katolicka, t. VI, red. J. Walkusz, Lublin 1993, s. 503-504; J. Cis ek, Oskar Halecki. Historyk - szermierz wolności, Warszawa 2009, s. 16-18.

${ }^{4}$ Halecki był zwolennikiem Ligi Narodów, która od samego początku uznawał za instytucję zgodną $z$ chrześcijańska koncepcja organizacji międzynarodowej. Szerzej na ten temat: A.M. Brzezińs ki, Oskar Halecki a Liga Narodów. Poglady i działalność, Łódź 2016.

${ }^{5}$ W 1927 r. Halecki został wyróżniony Komandorią Orderu Świętego Grzegorza Wielkiego, najwyższym odznaczeniem watykańskim nadawanym osobom świeckim. J. Cis e k, op. cit., s. 44.

${ }^{6}$ Ks. J. W a s ow ic z SDB, Kontakty prof. Oskara Haleckiego z kard. Augustem Hlondem SDB Prymasem Polski, „Seminare” 2015, t. XXXVI, nr 1, s. 227-234. 
Można przypuszczać, że motywy udziału Haleckiego w obchodach wiktorii wiedeńskiej wynikały nie tylko $z$ racji wykonywanego zawodu i wyznawanego światopoglądu. Nie można też wykluczyć osobistego, sentymentalnego wątku, pobudzonego rocznica wiedeńską. Halecki, który stał się Polakiem z przemyślanego wyboru, urodził się w Wiedniu (1891), spędził w nim dzieciństwo i lata młodzieńcze. Zdał maturę w jednej z najlepszych szkół austriackiej stolicy (Obergymnasium zu den Schotten). Wychowywał się w domu, w którym „austriacka identyfikacja państwowa szła w parze $z$ wola powrotu do polskich korzeni" .

Halecki już 1 stycznia 1933 r. opublikował obszerny artykuł analizujący znaczenie zwycięstwa pod Wiedniem w 1683 r. w „Kurierze Warszawskim", popularnym dzienniku o profilu katolickim i narodowym. Profesor zapewne zamierzał w ten sposób upowszechnić tekst wśród możliwie szerokiego grona czytelników. Tytuł tekstu: Polska-przedmurzem chrześcijaństwa. 1683-1933. O co walczono pod Wiedniem? wyrażał pogląd uczonego o dziejowej roli Polski jako obrońcy chrześcijaństwa, nie tylko w minionych wiekach, lecz także współcześnie ${ }^{8}$.

Profesor przypomniał, że w 1933 r. przypadają rocznice ważnych w dziejach Polski wydarzeń: rozpoczętego w 1333 r. „długiego i świetnego panowania" Kazimierza Wielkiego oraz urodzin przed czterema wiekami Stefana Batorego, który jako polski król „w ciagu krótkich lat dziesięciu” dodał wiele blasku „Polsce Zygmuntowskiej”. Zaznaczył jednak, że obie te rocznice „zapewne przyćmi” trzecia - 250 rocznica odsieczy wiedeńskiej pod wodzą Jana III

7 M. Salamon, Oskar Halecki na Uniwersytecie Jagiellońskim (1909-1918), [w:] Oskar Halecki i jego wizja Europy, red. M. Dabrowska, t. I, Warszawa-Łódź 2012, s. 18. Ojciec profesora, Oskar Ritten von Halecki (1838-1903), którego $z$ polskością łączył jedynie odległy rodowód, dosłużył się stopnia feldmarszałka-porucznika armii austrowęgierskiej. Por. J. Cis ek, op. cit., s. 11.

${ }^{8}$ Halecki uważał, że powstrzymanie i odparcie przez Polskę ofensywy sowieckiej w 1920 r. ocaliło chrześcijańską Europę, ale nie wyeliminowało bolszewickiego zagrożenia. W grudniu 1936 r., w wywiadzie udzielonym redakcji wydawanej w Wiedniu katolickiej gazety „Reichspost”, uczony powiedział, że sytuacja Polski pod wieloma względami przypomina położenie Austrii w okresie zagrożenia ze strony Turcji w 1683 r. Bitwa pod Warszawa w 1920 r., powstrzymująca najazd bolszewicki, miała podobne znaczenie jak odsiecz Wiednia. Profesor mówił, że bolszewizm jest nadal zagrożeniem dla Polski i Europy. Polska będzie więc odgrywać rolę „przedmurza” chrześcijaństwa w Europie przed „bezbożnictwem bolszewickim”. Polska nadal przedmurzem Europy, „Ilustrowany Kuryer Codzienny”, 19 XII 1936, nr 352, s. 7. 
Sobieskiego, która „będziemy obchodzili z całym światem chrześcijańskim”. Nie ma bowiem - pisał profesor - „wizji historycznej, która by silniej przemawiała do duszy polskiej", a na całym świecie nie ma bardziej znanego niż Sobieski nazwiska, „wśród tych nawet, którzy nie znaja żadnego innego nazwiska $z$ naszych dziejów”. Halecki zwrócił zarazem uwagę, że wokół tej „naprawdę niepowszedniej” rocznicy „krytyczny umysł współczesnego człowieka” zażąda wyjaśnienia „podwójnej wątpliwości”. Cudzoziemiec zapyta, czy „naprawdę o zwycięstwie wiedeńskim rozstrzygnęli Polacy z Janem III na czele”. Tę wątpliwość rozwiewa historyk wojskowości na podstawie „pozytywnych świadczeń źródłowych”, mając za sobą jednolitą, zgodna $z$ tradycja „opinię całej Polski”. Polak natomiast może wyrazić wątpliwość, czy „ten błyskotliwy gest orężny nie był zarazem zwykłym błędem politycznym”. "Tak modna dziś - pisał Halecki - skłonność do rewizji wszystkich poglądów na przeszłość i na jej najwybitniejsze postacie, ta skłonność znajduje tu niezwykle wdzięczne pole do argumentacji”. Profesor stwierdził, że dla odparcia tej argumentacji nie wystarczy analiza źródeł do „kampanii 1683 r." - należy rozpatrzeć ją na szerokim tle dziejów Polski i Europy. Dopiero wtedy „z mroków wątpliwości sceptycznych wyłoni się odpowiedź na pytanie, o co walczono pod Wiedniem".

Punktem wyjścia wywodu Haleckiego było stwierdzenie, że odsiecz Wiednia nie była „epizodem” w dziejach państwa polskiego. Od XIV w. Polska, ze względu na położenie geograficzne, odgrywała rolę „przedmurza chrześcijaństwa a zarazem broniła własnego bytu, nie przed Turkami, lecz przed Tatarami”. Jednak już w pierwszej połowie XV w. „niebezpieczeństwo tureckie zbliżało się w niepokojący sposób ku granicom Polski”. „Nieunikniona” walka $z$ Turkami wynikała zarówno ze względu na „niezatracona jeszcze całkowicie solidarność chrześcijańska, jak i z punktu widzenia polskiej racji stanu". Jednak w następstwie klęski pod Warną w $1444 \mathrm{r}$. i zhołdowaniu Krymu przez Turcję w 1475 r. sytuacja Polski stała się wyjątkowo niekorzystna. „Odtąd wiekowa plaga - pisał Halecki - jaką były dla Polski najazdy tatarskie, stała się szczególnie dotkliwa, bo kierowała nimi nie tylko moskiewska, ale i sułtańska ręka, a w utraconych przez Polskę i Litwę stepach czarnomorskich stykali się ze sobą Turcy z Tatarami”. Próba rozerwania zaciskającej się „obręczy muzułmańskiej” skończyła się „sromotną klęską bukowińską" (1497). W następnych dziesięcioleciach „Jagiellono- 
wie, zepchnięci ze szczytu swej potęgi, stracili wiarę w możliwość przeciwstawienia się Turkom”. Polityka „bierności i ostrożności” wobec Turcji była „smutna koniecznościa, przy pełnej świadomości ciagle grożącego $z$ tej strony niebezpieczeństwa".

Halecki pisał, że Rzeczpospolita, wzmocniona w drugiej połowie XVI w. (unia lubelska, zdobycie Inflant, zwycięskie wojny z Moskwa), zbliżała się „z nieubłaganą logiką dziejową" do kolejnych - wojen z Turkami, „do Cecory i Chocimia”. Szczególnie groźne dla bytu państwowego Polski, „tak jeszcze potężnej w połowie XVII wieku”, było powstanie Bohdana Chmielnickiego, „ponieważ za kozaczyzną stał cały świat muzułmański”. Zwycięstwo pod Beresteczkiem (1651) nie zostało przez Polskę należycie wykorzystane, „nie usunęło ani chaosu jaki zapanował na Ukrainie, ani dalszego niebezpieczeństwa tatarsko-tureckiego". Wystapiło ono $z$ nową siła po krytycznych dla Rzeczpospolitej latach szwedzkiego „potopu”. Zdobycie przez Turków Kamieńca Podolskiego (1672) było „jak gdyby przypieczętowaniem wszystkich klęsk poprzednich, a $z$ wszystkich niekorzystnych traktatów, jakimi Polska musiała wówczas okupić swoje istnienie, żaden nie był tak haniebny, jak traktat buczacki z Turcja”.

Charakteryzując politykę Jana III Sobieskiego, profesor zaznaczył, że okazał się „nie tylko genialnym wodzem ale i znakomitym dyplomata”. Po wyborze na króla polskiego (1674) Sobieski nie podjał natychmiast walki $z$ Turcja. Nie poszedł za głosem „opinii publicznej, tak zgodnym zreszta z porywami własnej duszy". Szukał rozwiązania konfliktu droga pokojowa za pośrednictwem sprzymierzonej Francji, ale wiara w pomoc Ludwika XIV okazała się zawodna. Wtedy monarcha polski zdecydował się na współpracę z Austria - „polityki u nas niepopularnej, zarówno w opinii szlacheckiej dawnej Rzeczypospolitej, jak i historiografii dzisiejszej”. Halecki uważał, że decyzja króla była trafna. Austria bowiem udzieliła Polsce pomocy w okresie szwedzkiego „potopu” oraz łączyła ja z Rzeczpospolita „wspólność interesu w obronie przeciwko Turkom”. Sojusz $z$ Austrią był dla Sobieskiego środkiem do osiagnięcia tego zasadniczego celu. Był także „ogniwem w wielkim planie ligi chrześcijańskiej”, który król pragnął urzeczywistnić, zwracając się nie tylko do Wiednia i Rzymu, lecz także dworów zachodnich.

Traktat $z$ Austria (31 marca 1683) przewidywał, że w razie ataku tureckiego na stolicę jednego $z$ układających się państw wład- 
ca drugiego natychmiast pospieszy z pomoca. Halecki zaznaczył, że $z$ góry zakładano atak na Wiedeń i pomoc polskiego króla niż znacznie mniej prawdopodobna sytuację odwrotna. Było jednak oczywiste, że upadek Wiednia zagrażałby kolejnym krajom i „całemu chrześcijaństwu”. Profesor pisał, że „naród polski byłby się sprzeniewierzył całej swej przeszłości, byłby się zaparł wszelkiego posłannictwa dziejowego, gdyby wobec takiego widowiska pozostał obojętny”. Wielkość Sobieskiego polegała na tym, że „wytknął sobie cel, który musiał przemówić do najszlachetniejszych pierwiastków psychiki narodowej”. Podobnie jak pod wrażeniem obrony Częstochowy w okresie najazdu szwedzkiego, tak i w 1683 r. „przygasający już płomień patriotyzmu polskiego rozpalił się na nowo pod ożywczym tchnieniem ideału religijnego". Zdaniem Haleckiego "przypływ moralnych sił”, jaki nastapił w 1683 r., pozwolił Polsce „przetrwać jeszcze przez cały wiek, mimo niepowstrzymanego zaniku sił politycznych i wszelkich innych".

Oceniając „realne” korzyści państwa polskiego $z$ odniesionego pod Wiedniem zwycięstwa, Halecki stwierdził, że dało ono jedynie „rezultat najniezbędniejszy”. Turcja na zawsze przestała być zagrożeniem dla Europy i Polski w szczególności. Natomiast z punktu widzenia interesu Polski „zawiodły nadzieje” na trwały wzrost jej znaczenia politycznego i rozszerzenia granic, które by „powetowało tyle świeżych i bolesnych strat terytorialnych". Uczony podkreślił, że Sobieski „nie doczekał się nawet odzyskania Kamieńca!”.

W końcowej części artykułu profesor napisał, że „czas najwyższy” zerwać z poglądem, który do tej pory „pokutuje” w publicystyce, jakoby pomoc udzielona Austrii przeciwko Turcji w 1683 r. była błędem, ponieważ sto lat później państwo to wzięło udział w rozbiorach Rzeczpospolitej, natomiast Turcja ich nie uznała. Halecki stwierdził, że jest to pogląd „anachroniczny”, „pragnący wytłumaczyć r. 1683 nie w świetle sytuacji ówczesnej, wytworzonej przez poprzednie wieki, lecz za pomocą wydarzeń wiele późniejszych, nie pozostających $z$ odsiecza Wiednia w żadnym związu przyczynowym”. Pogląd ten „tłumaczy się tym, że przywykliśmy w latach niewoli patrzeć na cała przeszłość Rzeczypospolitej z punktu widzenia - jej rozbiorów".

Halecki pisał, że wiktoria wiedeńska jest „jedną z najchlubniejszych rocznic dziejów polskich”. W Polsce „rozbitej i sponiewieranej wspomnienie 1693 r. było kapitałem moralnym, z którego korzy- 
staliśmy nieustannie, czerpiąc zeń wiarę we własne siły żywotne, zyskując sympatię i poważanie u obcych. Jedno i drugie - zaznaczył - dziś również bardzo nam się przyda" 9 .

Zawarta w artykule Haleckiego ocenę odsieczy Wiednia i jej znaczenia w historii Polski i Europy można uznać za interpretacyjna wskazówkę przed planowanymi przez władze państwowe i kościelne jubileuszowymi obchodami rocznicy wiedeńskiej. Wskazywała na dziejowa misję Polski jako „przedmurza chrześcijaństwa”, która wypełniała od XIV w. Udział Rzeczypospolitej w odsieczy Wiednia był kontynuacją tej misji a zarazem najbardziej znaczacym aktem w obronie chrześcijańskiej Europy i cywilizacji. Był to pogląd zgodny $z$ oficjalnym stanowiskiem Kościoła. Wyraził to kilka miesięcy później prymas kardynał August Hlond w Zarzadzeniu w sprawie obchodów rocznicy odsieczy Wiednia z 24 sierpnia 1933 r. Prymas napisał, że uczestnicząc w odsieczy Wiednia, Polska „uratowała chrześcijaństwo i kulturę zachodnia”. Motywem udziału w bitwie „był nakaz naszych dziejów i niezawodny instynkt posłannictwa Polski” w dziedzinie „kulturalnej i religijnej”. Czyn wiedeński - pisał - był jednym $z$ „epizodów naszej ofiarnej służby na wysuniętym posterunku wschodnim, dlatego od innych głośniejszy, że rozegrał się w obliczu świata chrześcijańskiego i na jego szczególną korzyść". Prymas Hlond podkreślił, że zwycięstwo pod Wiedniem ma „przede wszystkim znaczenie religijne”. Polecał uczcić rocznicę wiedeńską "nabożeństwem dziękczynnym a zarazem modłami o pomyślność dla Państwa i o błogosławieństwo boże dla dalszego posłannictwa Polski"10.

Pisząc omówiony powyżej artykuł, Halecki zapewne nie przypuszczał, że przypadnie mu wygłoszenie okolicznościowego referatu podczas centralnych jubileuszowych obchodów zwycięstwa

${ }^{9}$ O. Halecki, Polska-przedmurzem chrześcijaństwa. 1683-1933. O co walczono pod Wiedniem?, „Kurier Warszawski”, 1 I 1933, nr 1, s. 10-11.

10 Prymas zarzadził odprawienie w niedzielę, 10 IX sumy jako nabożeństwa dziękczynnego i wygłoszenie przez księży kazań o zwycięstwie wiedeńskim, „słusznie" nazwanym gesta Dei per Polonos. Natomiast 12 IX o godzinie 18, kiedy przed 250 laty „pod natarciem rycerstwa polskiego sprzymierzone armie chrześcijańskie po całodziennej mozolnej walce odniosły owe wielkie zwycięstwo", miały bić dzwony wszystkich kościołów, „wzywając do modlitwy za Polskę, by dochowała wierności swoim tradycjom chrześcijańskim, swej wierze, swemu duchowi i posłannictwu". Prymas polecał duchowieństwu i organizacjom katolickim udział w komitetach obchodowych. „Miesięcznik Kościelny Archidiecezyj Gnieźnieńskiej i Poznańskiej” 1933, nr 9, s. 69; także August Kardynał Hlond Prymas Polski, Dzieła. Nauczanie 1897-1948, t. I, Toruń 2003, s. 385. 
wiedeńskiego w stolicy Austrii. Inicjatywa wspólnego polsko-austriackiego uczczenia 250 rocznicy odsieczy Wiednia wyszła z Warszawy za pośrednictwem poselstwa polskiego w Austrii. Organizację wspólnych obchodów Ministerstwo Spraw Zagranicznych (MSZ) powierzyło dr. Juliuszowi Twardowskiemu, radcy poselstwa RP w randze ministra, doskonale zorientowanemu w realiach austriackich ${ }^{11}$. Rząd Engelberta Dollfussa nie wyraził jednak na to zgody, obawiajac się negatywnej reakcji ze strony władz Trzeciej Rzeszy. Nie chcąc zadrażniać stosunków z rządem Adolfa Hitlera, w poczuciu zagrożenia austriackiej suwerenności, odrzucono koncepcję wspólnego z Polską obchodu. Tłumaczono radcy Twardowskiemu, że w Berlinie mogłoby to zostać odczytane jako „bratanie się polsko-austriackie" i wykorzystane przez nazistów przeciwko rządowi Dollfussa. Deklarowano natomiast udział austriackich władz państwowych i kościelnych w polskich uroczystościach ${ }^{12}$.

W końcu czerwca 1933 r. ustalony został program odrębnych polskich obchodów w Wiedniu. Przewidziano, że 12 września w godzinach porannych celebrowana będzie uroczysta msza na wzgórzu Kahlenberg, z którego w 1683 r. Jan III Sobieski poprowadził wojsko do zwycięskiej bitwy. Następnego dnia wieczorem miała odbyć się okolicznościowa akademia w Grosser Musikvereinsaal w Wiedniu. Program akademii przewidywał wystapienie prymasa Polski o charakterze religijnym, okolicznościowy referat profesora Haleckiego oraz część artystyczna. Ostatnim akordem polskiego obchodu zwycięstwa wiedeńskiego miało być przyjęcie w salach poselstwa $\mathrm{RP}^{13}$.

11 Juliusz Twardowski (1874-1945) odbył studia prawnicze na Uniwersytecie Wiedeńskim i Uniwersytecie Lwowskim (1892-1897), uzyskując stopień doktora praw. W latach 1898-1918 pozostawał w austriackiej służbie państwowej (Prokuratoria Skarbu, Ministerstwo Handlu, Ministerstwo Robót Publicznych, Ministerstwo do spraw Galicji), podczas I wojny światowej był przewodniczącym Komitetu Pomocy Uchodźcom z Galicji i Bukowiny. Po odzyskaniu przez Polskę niepodległości został pełnomocnikiem Głównego Urzędu Likwidacyjnego (1919); od 1921 r. był prezesem zorganizowanej przez siebie Polsko-Austriackiej Izby Handlowej, w latach 1918-1929 był aktywnym działaczem „Domu Polskiego” w Wiedniu i prezesem Związku Stowarzyszeń Polskich tamże; w latach 1924-1929 był prezesem Towarzystwa Opieki nad Szkolnictwem Polskim w Wiedniu. W latach 1928-1930 piastował funkcje szefa delegacji polskiej na rokowania w Warszawie dotyczace I traktatu handlowego $z$ Niemcami. Materiały na temat działalności J. Twardowskiego znajduja się w Archiwum Akt Nowych w Warszawie - Zespół: 2/104/0. Akta Juliusza Twardowskiego.

12 Z. Maj, op. cit., s. 42.

13 Program austriackich obchodów przewidywał festyn ludowy na Heldenplatz 11 IX, a następnego dnia uroczystości oficjalne - mszę polową celebrowana przez 
Dnia 20 lipca 1933 r. minister spraw zagranicznych Józef Beck mianował dr. J. Twardowskiego „Delegatem Rządu Polskiego” na uroczystościach 250 rocznicy odsieczy Wiednia, co ze względów protokolarnych znacznie ułatwiało dyplomacie ostateczne przygotowanie obchodu. Rząd RP miała reprezentować jedynie trzyosobowa delegacja wojskowa na czele $z$ gen. Bolesławem Wieniawą-Długoszowskim, dowódca 2 Dywizji Kawalerii ${ }^{14}$. Uczestnictwo w uroczystościach potwierdził prymas A. Hlond oraz biskup chełmiński Stanisław Wojciech Okoniewski. Władze kościelne Drugiej Rzeczypospolitej $z$ pomoca instytucji państwowych zorganizowały pielgrzymki Polaków na uroczystości jubileuszowe w Wiedniu, aby przez możliwie liczną ich obecność podkreślić rangę obchodów ${ }^{15}$.

Powierzenie Haleckiemu roli referenta podczas akademii $z$ okazji 250 rocznicy wiktorii wiedeńskiej w stolicy Austrii było wyrazem uznania przez władze kościelne i rządowe dla jego wiedzy, głoszonych poglądów i postawy moralnej. Kandydatura profesora była zapewne wynikiem konsultacji MSZ z prymasem Hlondem, z którym - jak wspomniano - Halecki pozostawał w kontakcie

prymasa Austrii kardynała Teodora Innitzera, przemówienie prezydenta Austrii Wilhelma Miklasa oraz składanie wieńców pod pomnikiem księcia Eugeniusza Sabaudzkiego, uczestnika bitwy wiedeńskiej. Por. ibidem, s. 43.

${ }^{14}$ Prawdopodobnie stosunkowo niski stopień delegacji władz państwowych RP był spowodowany fiaskiem propozycji wspólnych z Austrią obchodów odsieczy Wiednia oraz jej głównie religijnym charakterem. Rząd RP podjał też decyzję, aby niezależnie od obchodów rocznicowych w całej Polsce 12 IX zorganizować Święto Kawalerii Polskiej na krakowskich Błoniach 6 X. Defiladę 12 pułków kawalerii odebrali wtedy prezydent RP Ignacy Mościcki, marszałek Józef Piłsudski, generalicja polska oraz liczni dyplomaci zagraniczni. Delegacja $z$ marszałkiem Piłsudskim na czele oddała cześć przed sarkofagiem Jana III Sobieskiego w katedrze wawelskiej. Por. W. Rezmer, Rewia polskiej kawalerii w Krakowie w 1933 roku, „Przegląd Historyczno-Wojskowy" 2013, t. XIV, nr 3 (245), s. 127-144: D. Wy b r a now s ki, op. cit., s. 83; M. Kunicki-Goldfinger, op. cit., s. 80.

15 Wyrazem zaangażowania prymasa Hlonda w tej sprawie było przewodniczenie pielgrzymce $z$ Katowic liczącej ok. 600 osób. Kalendarium życia kard. Augusta Hlonda, http://www.patrimonium.chrystusowcy.pl/kandydaci-na-oltarze/sluga-bozy-kard-august-hlond/schemat biograficzny/\#.WlzQtbjWOwA (dostęp: 17 XII 2017). Na uroczystości wiedeńskie przyjechał arcybiskup Adam Sapieha z Krakowa, arcybiskup (obrzędu ormiańskiego) Józef Teodorowicz i biskup polowy Józef Gawlina. W przeddzień rocznicy wiedeńskiej arcybiskup A. Sapieha celebrował mszę pontyfikalna w kościele polskim (Rennweg 5A). Kazanie wygłosił biskup polowy J. Gawlina. Porównał zwycięstwo wiedeńskie z bitwą warszawską 1920 r., która ocaliła Polskę i Europe przed bolszewizmem. Pod Wiedniem i Warszawa ocaliła Polska Europę. Kazanie ks. biskupa Gawliny w kościele polskim w Wiedniu, „Ilustrowany Kuryer Codzienny”, 13 IX 1933, nr 254, s. 13. 
i uczestniczył na jego zaproszenie w uroczystościach religijnych. Profesor był bardzo dobrze znany MSZ z okresu jego działalności w Lidze Narodów oraz doraźnych konsultacji. Wspomnieć należy, że od 1931 r. Halecki zaangażował się w propagowanie w kraju i za granica, głównie w środowiskach katolickich, rzadowego projektu międzynarodowej konwencji o rozbrojeniu moralnym, który uważał za zgodny z nauka Kościoła ${ }^{16}$.

Polskie obchody 250 rocznicy wiktorii wiedeńskiej odbyły się w stolicy Austrii zgodnie z przyjętymi ustaleniami. Rozpoczęły się we wtorek, 12 września. Od godzin porannych na udekorowanym polskimi i austriackimi flagami Kahlenbergu zgromadził się tłum ok. 10 tys. osób, w tym 3-5 tys. pielgrzymów z Polski i Polonii austriackiej. Przybyli prezydent Austrii Wilhelm Miklas, kanclerz E. Dollfuss, przedstawiciele armii i duchowieństwa. Odegrane zostały hymny Austrii i Polski. Kanclerz i przedstawiciel austriackiego wojska złożyli wieńce w Kaplicy Sobieskiego przylegającej do kościoła św. Józefa. Następnie odbyła się uroczysta msza celebrowana przez prymasa Hlonda. Biskup Stanisław Okoniewski wygłosił „płomienne kazanie”, najpierw w języku polskim, potem w niemieckim. Obrazowo przedstawił wydarzenia na Kahlenbergu sprzed 250 lat i rolę Jana III Sobieskiego, „chrześcijańskiego króla-rycerza", w poprowadzeniu wojska do zwycięskiej bitwy, poprzedzone jego udziałem w uroczystej mszy ${ }^{17}$.

Dnia 13 września 1933 r. o godzinie 20 rozpoczęła się uroczysta akademia, transmitowana $\mathrm{w}$ całości przez radio. $\mathrm{W}$ przystrojonej polskimi i austriackimi sztandarami wiedeńskiej Grosser Musikvereinsaal, mogącej pomieścić ok. 2 tys. osób, zgromadzili się głównie wiedeńczycy. Obecny był kanclerz E. Dollfuss, członkowie rzadu, dostojnicy kościelni $z$ kardynałem T. Innitzerem, członkowie korpusu dyplomatycznego, delegacja wojskowa $z$ gen. Wieniawa-Długoszowskim. Orkiestra odegrała hymny Austrii i Polski. W imieniu rządu RP akademię otworzył dr J. Twardowski, podkreślając znaczenie udziału wojsk polskich, walczących wspólnie z Niemcami i Austriakami, w zwycięskiej bitwie pod Wiedniem. Stwierdzenie,

\footnotetext{
${ }^{16}$ Por. A.M. Brzeziński, op. cit., s. 231-259.

17 Biskup podkreślił, że Jan III Sobieski polecił obecnemu na Kahlenbergu legatowi papieskiemu Markowi d'Aviano odprawienie mszy o godzinie 4 rano, aby „uprosić szczególniejszą opiekę aniołów stróżów nad rozpoczynająca się bitwą. Tam padł na kolana, tam skrzyżował na piersi ramiona i posługe czynił przez cała mszę św. jako zwykły ministrant...” Ks. F. Fe recki, $Z$ wielkich dni rocznicy wiedeńskiej, „Przewodnik Katolicki” [Poznań] 1933, R. XXXIX, nr 40, s. 633.
} 
że „święcimy wspólną akcję i wspólne zwycięstwo” sprzed 250 lat, mogło być odebrane jako aluzja do niezrealizowanej koncepcji wspólnych austriacko-polskich obchodów odsieczy Wiednia ${ }^{18}$. Twardowski, a następnie prymas Hlond i profesor Halecki przemawiali po niemiecku.

Prymas Hlond zaznaczył, że „harmonia i pokój były zasadnicza myśla polskich obchodów oswobodzenia Wiednia". Podkreślił, że nigdzie nie występowały „uczucia nienawiści przeciw byłemu przeciwnikowi” lub „słowa zniewagi dla rycerskiego narodu tureckiego”. W atmosferze „harmonii i pokoju” przebiegała także - jak zaznaczył duchowny - „wczorajsza” uroczystość na Kahlenbergu. „W oczyszczonej świadomości narodowej - mówił prymas - ze szczera gotowością do współpracy przy dziele pokoju światowego stała pielgrzymia rzesza polska, stali spadkobiercy i potomkowie dawnego zwycięzcy, modląc się na historycznym wzgórzu, które wieczyście związane zostało z imieniem i sławą pobożnego i dobrego króla Polaków".

Prymas Hlond dał do zrozumienia, że chrześcijańskiej Polsce obce są ideologie nazizmu i komunizmu. Podkreślał, że „Polska świadoma jest swej godności narodowej, swej myśli państwowej, swego dziejowego posłannictwa”. Polskie rozumienie "harmonii i pokoju” opiera się na realnej ocenie rzeczywistości. Polacy „nie znaja ubóstwiania własnego narodu" i widza możliwość harmonii $z$ innymi narodami. Maja wstręt do wszystkiego gwałtu, wszelkiego ślepego fanatyzmu, wszelkich fałszów, wszelkich teorii o władztwie i niewolnictwie w życiu narodów”. Prymas podkreślił, że „Mimo całej przeszłości - mówił prymas - Polacy nikomu nic nie pamiętaja i chca poważnie współpracować przy odbudowie świata w duchu prawdziwie chrześcijańskiego braterstwa. Dalecy od rasowego wywyższania się, nie roszcząc sobie pretensji do uprzywilejowanego stanowiska $\mathrm{w}$ rodzinie ludów, gotowi są współdziałać $\mathrm{z}$ bliskim i dalekim, aby ustrzec się uchybień w rozwoju stosunków między ludami” ${ }^{19}$.

18 Twardowski wskazał na trzy istotne elementy udziału wojsk polskich w bitwie wiedeńskiej: 1) dowództwo „nad cała armią odsieczy spoczywało, w zgodnym współdziałaniu $z$ ks. Karolem Lotaryńskim, w ręku króla Jana III Sobieskiego”; 2) „kontyngent wojsk polskich był liczebnie najliczniejszy”; 3) „Zwrot decydujacy w bitwie, tzn. zmuszenie wroga do ucieczki spowodowany został kierowanym osobiście przez króla Sobieskiego atakiem opancerzonej husarii polskiej”. Według Uroczysta akademia $w$ Wiedniu dla uczczenia 250-lecia odsieczy, "Goniec Częstochowski", 16 IX 1933, nr 212, s. 1-2.

19 Przemówienie prymasa Hlonda na uroczystej akademii z okazji 250-lecia odsieczy wiedeńskiej w sali Filharmonii w Wiedniu. Druk: „Roczniki Katolickie” 
Halecki zabrał głos po wystapieniu prymasa Hlonda. Wykład zatytułowany Oswobodzenie Wiednia i jego znaczenie dla Austrii, Polski i Europy uczony wygłosił z pamięci „swobodnie, bez najmniejszego wysiłku". Profesor nawiązał do podniesionej przez prymasa kwestii pokojowego współżycia narodów. Rozpoczał od uwagi, że rocznica odsieczy wiedeńskiej świętowana jest w chwili, gdy „serca owłada powszechnie tęsknota za pokojem". Zaznaczył również, że obchodzone jest zwycięstwo nad narodem, „który ani dla Austriaków ani dla Polaków nie jest już wrogiem". Powiedział, że odsiecz Wiednia umożliwiła Austrii stać się „ojczyzną wielkich ludzi, przybytkiem sztuki”, umiejącej zarazem „uznać i uszanować wartości ducha innych narodów".

Zaznaczył, że Austria w połowie XVII w. nie była w stanie sama oprzeć się Turkom i obronić Wiedeń. „Patriota austriacki” może być jednak dumny, że nie pozostał osamotniony i uzyskał pomoc $z$ zewnattrz. Jan III Sobieski ruszył na odsiecz Wiednia $z$ głębokim przeświadczeniem, nabytym w toku „bezustannych” walk z Turkami, że należy ich zwalczać i podjąć walkę, nie za Austrię, ale za „największy ideał chrześcijaństwa, za wiarę Chrystusowa”. W 1683 r. Rzeczpospolita miała za soba stulecie nieprzerwanych wojen, „stojąc na straży całej Europy, będąc prawdziwym przedmurzem chrześcijaństwa”. O ile w Europie zapomniano o tych „niezliczonych świetnych zwycięstwach", to jedno zwycięstwo Polaków pod Wiedniem „znane jest całemu światu”. Dzieje się tak dlatego, że zwycięstwo pod Wiedniem jest „nierozerwalnie złączone $z$ bezprzykładna $\mathrm{w}$ swej bezinteresowności ofiarnością całego narodu polskiego".

Profesor podkreślił, że wystawiona przez Polskę 30-tysięczna armia była, jak na połowę XVII w., armia „potężna”, Wysiłek zbrojny Polski był dyktowany nie tylko patriotyzmem (Polska chciała odzyskać zabrane przez Turków Podole), ale głównie „tradycjami chrześcijańskimi” Polaków. W 1683 r. żyli jeszcze weterani 1655 r. walczacy $z$ najazdem szwedzkim, pamiętajacy obronę Jasnej Góry, którzy „własną krwią pieczętowali przynależność do Kościoła katolickiego".

Profesor powiedział, że na rok 1683 należy patrzeć z punktu widzenia „idei uniwersalności”. Austria i Polska, państwo germańskie i państwo słowiańskie, „spotkały się w owej epoce na wspól-

12 (1934), s. 120-121; także: August Kardynał Hlond Prymas Polski, Dzieła, s. 389-390. 
nej platformie, wzbudzając w sobie dawnego ducha rzymskiego". Halecki zwrócił uwagę, że w 1453 r., kiedy Turcy zdobyli Konstantynopol, zabrakło woli walki do obrony chrześcijaństwa, gdyż ludzie byli wówczas „za słabi, za mali, nie dorośli do posłannictwa jakie im Opatrzność nakładała na barki, Nie zrozumieli wówczas tego, co zrozumieli Polacy w 1683 r.”. Halecki zakończył wystąpienie stwierdzeniem, że odsiecz Wiednia jako „czyn historyczny” powinien być „gwiazda przewodnia”, która poprowadzi oba narody „pod znakiem krzyża”20.

Wystapienie profesora zawierało zasadnicze tezy jego artykułu opublikowanego w „Kurierze Warszawskim” 1 stycznia 1933 r. Wskazywał, że uczestnicząc w odsieczy Wiednia, Polska odegrała bardziej niż kiedykolwiek rolę „przedmurza” chrześcijaństwa. Podkreślił znaczacy udział wojska polskich pod wodza Jana III Sobieskiego w zwycięskiej bitwie nad tureckim najeźdźcą. Zaznaczył zarazem, że idea obrony chrześcijaństwa połączyła wtedy Austrię i Polskę we wspólnej walce. W wystapieniu Haleckiego znalazły się także akcenty nawiązujące do wypowiedzi prymasa Hlonda o polskim rozumieniu „harmonii i pokoju”. Obaj podkreślili, że Turcja nie jest aktualnym wrogiem ani Polski, ani Austrii. Było to zgodne $z$ wytycznymi polskiego MSZ, aby w oficjalnych wystapieniach rocznicowych nie akcentować Turcji jako wrogiego państwa ${ }^{21}$.

Kolejnym wyrazem zaangażowania Haleckiego w obchody 250 rocznicy odsieczy wiedeńskiej było wydanie okolicznościowego

${ }^{20}$ Stosunkowo najpełniejsze streszczenie wystapienia Haleckiego napisał uczestnik akademii ks. Franciszek Forecki na łamach „Przewodnika Katolickiego”, zamieścił też fotografię profesora. Zwrócił uwagę, że w prasie polskiej wiedeńskie wystapienie Haleckiego przedstawiono lakonicznie bądź je pomijano. „Nadziwić się nie mogę - pisał - że w innych polskich pismach nie znajduję tego bodaj najświetniejszego referatu całego zjazdu. Żałuję także, że sala nie była wypełniona po brzegi. Było nas przecież około 3000 Polaków w Wiedniu i mogliśmy z łatwościa wypełnić dwa razy większa salę”. $Z$ wielkich dni rocznicy wiedeńskiej, „Przewodnik Katolicki” [Poznań] 1933, R. XXXIX, nr 40, s. 634. Por. Gdy państwo słowiańskie niosło pomoc państwu germańskiemu. Uroczysta akademia $w$ Wiedniu dla uczczenia 250-lecia odsieczy, „Ilustrowany Kuryer Codzienny”, 15 IX 1933, nr 256, s. 4; Akademia polska dla uczczenia 250-lecia odsieczy, „Głos Narodu”, 15 IX 1933, nr 248, s. 3; Uroczystości na cześć 25-lecia odsieczy Wiednia, „Kurier Warszawski”, 13 IX 1933, nr 253, s. 1; Uroczysta akademia $w$ Wiedniu dla uczczenia 250-lecia odsieczy, „Goniec Częstochowski”, 16 IX 1933, nr 212, s. 1-2. Uczestnik akademii odnotował, że po wystapieniu Haleckiego „zerwał się na sali huragan niemilknących oklasków, by podziękować świetnemu mówcy za tak wspaniały wykład". Ks. F. Ferecki, op. cit., s. 634.

${ }^{21}$ Z. Maj, op. cit., s. 80-81. 
numeru redagowanego przez niego „Miesięcznika Heraldycznego”. Wrześniowy zeszyt periodyku, wydawanego przez Warszawski Oddział Polskiego Towarzystwa Heraldycznego, którego profesor był prezesem, poświęcono „Pamięci Rycerzy Polskich, którzy 12 września 1683 roku pod wodza króla Jana Sobieskiego przez udział w odsieczy Wiednia wsławili imię polskie w całym chrześcijańskim świecie".

$\mathrm{W}$ otwierajacym zeszyt artykule, zatytułowanym $W$ rocznice odsieczy Wiednia, Halecki porównywał historyczne znaczenie bitwy pod Wiedniem ze starciem pod Grunwaldem. Pisał, że te dwa zwycięstwa „słusznie można postawić obok siebie, ponieważ w tysiącletnich dziejach narodu polskiego chyba jedna tylko bitwę pod Warszawą z r. 1920 z niemi porównać można". Chociaż zwycięstwa pod Grunwaldem i Wiedniem nie zostały „wyzyskane należycie”, to tak okryły Polskę "trwałą sławą" i miały tak "głębokie znaczenie moralne”, że „pamięć ich nigdy nie przestała poruszać serc i umysłów następnych pokoleń".

Podobnie jak w artykule opublikowanym w „Kurierze Warszawskim" 1 stycznia 1933 r., profesor stwierdził, że pod Wiedniem Polska „odegrała, wyraźniej niż kiedykolwiek, rolę przedmurza Chrześcijaństwa przed muzułmańskim Wschodem". Halecki odrzucił „powierzchownym sąd”, który „po dziś dzień pokutuje w publicystyce”, że pod Wiedniem Polska „ratowała Niemców” wbrew własnemu interesowi. Profesor cytował ustalenia polskich historyków (Kazimierz Konarski, Władysław Konopczyński, Wacław Sobieski, Kazimierz Piwarski, Marian Kukiel), wskazujących, że odsiecz Wiednia była dyktowana realnym interesem polityczno-strategicznym kraju, ocaliła państwo polskie od zagłady tureckiej, obroniła Austrię i chrześcijaństwo. „Był więc i Wiedeń, wbrew pozorom, - pisał Halecki - takim samym jak Grunwald czynem przewidującej myśli politycznej”. W jednym i drugim przypadku „słusznej broniono sprawy” oraz jednej i tej samej zasady: „prawa wszystkich narodów do samodzielnego bytu wbrew zakusom obcych najeźdźców”.

Profesor podkreślał rolę Jana III Sobieskiego i wyzwoloną przez niego „niezwykła energię narodu” w zwycięstwie 1683 r. Zdaniem Haleckiego analogia między Grunwaldem i Wiedniem jest także „wspólna zasługa króla i narodu” w przygotowaniu i przeprowadzeniu „wielkiej wojny” z Krzyżakami i odsieczy wiedeńskiej. Podkreślił, że Jan III Sobieski był jedynym szlachcicem polskim, który zasiadł na tronie „całkiem legalnie, nie narzucony przez obce potęgi, 
lecz jednomyślnie wybrany przez brać szlachecka, widzącą w nim słusznie swego typowego - a to w najdodatniejszym znaczeniu - przedstawiciela”. Podkreślił również, że wojsko, które ten „król-szlachcic wiódł pod Wiedeń”, składało się w większości z polskiej szlachty. Profesor stwierdził, że „przeważający udział tej właśnie masy szlacheckiej w zwycięstwie oręża polskiego nigdy nie da się stwierdzić tak wyraźnie, jak właśnie pod Grunwaldem i Wiedniem". Artykuł kończył stwierdzeniem, że „bohaterowie” odsieczy wiedeńskiej „godnie zakończyli polską epopeję wojenną XVII-go wieku, odkupili winy rokoszan i królewiąt kresowych, a zanim nastał mrok czasów saskich, w obliczu całego świata chrześcijańskiego uratowali honor szlachty polskiej"22.

Reasumując, można stwierdzić, że Oskar Halecki uczestniczył w obchodach 250 rocznicy odsieczy wiedeńskiej jako historyk o katolickim światopogladzie, czemu dał wyraz w opublikowanych $z$ tej okazji artykułach. Podkreślał znaczenie udziału wojsk polskich pod wodza Jana III Sobieskiego w zwycięstwie wiedeńskim, które ocaliło chrześcijańską Europę i zachodnią cywilizację. Podkreślał, że było to kontynuacja dziejowej funkcji Polski jako „przedmurza” chrześcijaństwa, pełnionej od XIV w. Pogląd ten przedstawił również w referacie wygłoszonym po niemiecku podczas uroczystej akademii $z$ okazji polskich obchodów rocznicy wiedeńskiej w stolicy Austrii. Oceniał zwycięstwo pod Wiedniem jako jedno $z$ najbardziej chlubnych wydarzeń w dziejach Polski, mające zarazem epokowe znaczenie dla obrony cywilizacji chrześcijańskiej przed tureckim zagrożeniem. Odrzucał pogląd mówiący o tym, że udział Polski w odsieczy Wiednia był politycznym błędem.

\section{Bibliografia}

\section{ŹRódeA DRUKOWANE}

August Kardynał Hlond Prymas Polski, Dzieła. Nauczanie 1897-1948, t. I, Toruń 2003.

${ }^{22}$ O. Halecki, W rocznice odsieczy Wiednia, „Miesięcznik Heraldyczny” [Warszawa] 1933, R. XII, nr 9, s. 130-132. 
Prasa

Akademia polska dla uczczenia 250-lecia odsieczy, „Głos Narodu”, 15 IX 1933, nr 248, s. 3.

Ferecki F. ks., Z wielkich dni rocznicy wiedeńskiej, „Przewodnik Katolicki” [Poznań] 1933, R. XXXIX, nr 40, s. 633-634.

Gdy państwo słowiańskie niosło pomoc państwu germańskiemu. Uroczysta akademia w Wiedniu dla uczczenia 250-lecia odsieczy, „Ilustrowany Kuryer Codzienny", 15 IX 1933, nr 256, s. 4.

Halecki O., Polska - przedmurzem chrześcijaństwa. 1683-1933. O co walczono pod Wiedniem?, „Kurier Warszawski”, 1 I 1933, nr 1, s. 10-11.

Halecki O., W rocznice odsieczy Wiednia, „Miesięcznik Heraldyczny” [Warszawa] 1933, R. XII, nr 9, s. 130-132.

Pod Wiedniem i Warszawa ocaliła Polska Europę. Kazanie ks. biskupa Gawliny w kościele polskim w Wiedniu, „Ilustrowany Kuryer Codzienny”, 13 IX 1933, nr 254, s. 13.

Polska nadal przedmurzem Europy, „Ilustrowany Kuryer Codzienny”, 19 XII 1936, nr 352, s. 7.

Uroczysta akademia $w$ Wiedniu dla uczczenia 250-lecia odsieczy, „Goniec Częstochowski”, 16 IX 1933, nr 212, s. 1-2.

Uroczystości na cześć 25-lecia odsieczy Wiednia, „Kurier Warszawski”, 13 IX 1933, nr 253, s. 1.

\section{OpRacowania}

Anusik M., Anusik Z., Jan III Sobieski w tradycji historycznej czasów stanisławowskich, „Acta Universitatis Lodziensis”, Folia Historica 22, 1985, s. 79-89.

Barwiak Z., Oskar Halecki, [w:] Encyklopedia katolicka, t. VI, red. J. Walkusz, Lublin 1993, s. 503-504.

Brzeziński A.M., Oskar Halecki a Liga Narodów. Poglady i działalność, Łódź 2016.

Cisek J., Oskar Halecki. Historyk-Szermierz Wolności, Warszawa 2009.

Galos A., Obchody rocznicy wiedeńskiej w XIX wieku, „Śląski Kwartalnik Historyczny Sobótka" 1980, t. XXXV, nr 2, s. 433-439.

Kalendarium życia kard. Augusta Hlonda, http:/ / www.patrimonium.chrystusowcy.pl /kandydaci-na-oltarze/sluga-bozy-kard-august-hlond/schematbiograficzny/\#.WlzQtbjWOwA (dostęp: 17 XII 2017).

Kunicki-Goldfinger M., Obchody 250. rocznicy zwycięstwa Jana III pod Wiedniem w prasie polskiej roku 1933 (przeglad wstępny), „Studia Wilanowskie” [Warszawa] 2014, t. XXI, s. 73-87.

Maj Z., Obchody 250 rocznicy odsieczy wiedeńskiej wśród Polaków za granica ( $w$ świetle dokumentów z Archiwum Akt Nowych $w$ Warszawie), „Studia Wilanowskie" [Warszawa] 1983, t. IX, s. 39-84.

Maliszewski K., Kult Jana III Sobieskiego i wiktorii wiedeńskiej (1683) w polskiej kulturze i tradycji, „Czasy Nowożytne” 2010, t. XXIII, s. 47-62. 
Rezmer W., Rewia polskiej kawalerii w Krakowie w 1933 roku, „Przegląd Historyczno-Wojskowy" 2013, t. XIV, nr 3 (245), s. 127-144.

Rożek M., Zwycięstwo Jana III Sobieskiego pod Wiedniem. Echa Wiktorii, Kraków 2008.

Salamon M., Oskar Halecki na Uniwersytecie Jagiellońskim (1909-1918), [w:] Oskar Halecki i jego wizja Europy, red. M. Dąbrowska, t. I, Warszawa-Łódź 2012, s. $16-37$.

Śliziński J., Jan III Sobieski w literaturze narodów Europy, Warszawa 1979.

Wąsowicz J. ks. SDB, Kontakty prof. Oskara Haleckiego z kard. Augustem Hlondem SDB Prymasem Polski, „Seminare” 2015, t. XXXVI, nr 1, s. 227-234.

Wybranowski D., O niektórych mitach, nieścisłościach i kontrowersjach $w$ kwestii tureckiej wyprawy na Wieden w 1683 r., „Balcanica Posnaniensa” [Poznań] 2014 , t. XXI, s. 82-63.

Andrzej M. Brzeziński

\section{Oskar Halecki's contribution to the commemoration of the $250^{\text {th }}$ anniversary of the Rescue of Vienna in 1933}

$\mathrm{O}$ skar Halecki, a professor of the University of Warsaw and a renowned expert on world and Polish history, contributed to the commemoration of the $250^{\text {th }}$ anniversary of the Rescue of Vienna as a Catholic intellectual. In a series of articles, published for the occasion, professor Halecki emphasized the significance of the participation of Poland in the victorious battle against the Turks, fought outside Vienna on 12 September 1683, which saved the Christian Europe and Western civilization. Halecki argued that the Polish troops under the command of King John III Sobieski played, not for the first time, a historical role of the bulwark of Christianity it had assumed since the $14^{\text {th }}$ century. This view was further presented by Halecki in a lecture, given in German, entitled „Liberation of Vienna and Its Significance for Austria, Poland and Europe” during an official Polish celebration commemorating the Battle of Vienna anniversary held in the Austrian capital, on 13 September 1933. Oskar Halecki's vision of Poland's full awareness of its historical mission to defend the Christian faith complied with the official position of the Catholic Church expressed by Primate August Hlond in official writings and addresses delivered on the occasion of the $250^{\text {th }}$ anniversary of the victorious Battle of Vienna.

In an article „On the Anniversary of the Rescue of Vienna” opening a special issue of "Miesięcznik Heraldyczny”, a periodical edited by professor Halecki, the scholar compared the historical significance of the Battle of Vienna to the 1410 Battle of Grunwald. He claimed that in the thousand-year history of Poland these two victorious events could only be paralleled by the 1920 Battle of Warsaw that saved Poland and Europe from the advance of Bolshevism. According to Halecki, the Battle of Vienna, similarly to Grunwald, was „the act of anticipatory political thought." In both cases, he argued, it was „a fight for a noble cause" to "protect the nation's right to independence against the foreign invaders". Halecki rejected 
the view, expressed by some journalists, that Polish participation in the Rescue of Vienna and the act of saving Austria was actually a political mistake, as, a century later, Austria took part in the Partitions of Poland. He claimed that such reasoning was indeed anachronistic, as it explicated the events from 1683 not in view of the then political situation, determined by the previous centuries, but by means of later events which bore no causal relation to the Battle of Vienna.

Keywords: Oskar Halecki, primate August Hlond, Poland, Austria, 250 ${ }^{\text {th }}$ anniversary, rescue of Vienna 1683. 